\title{
TINGKAT KEPUASAN NASABAH TERHADAP KUALITAS LAYANAN PERBANKAN SYARIAH DI YOGYAKARTA
}

\author{
Putri Dwi Cahyani \\ University Muhammadiyah Purwokerto \\ putri.dece@gmail.com
}

\begin{abstract}
.
The Objective Of The Present Study Was To Find Out Service Quality's Factors that influences for customer satisfaction, the obtrusive criteria that affect customer satisfaction and analyze the level of customer satisfaction in each Islamic bank in Yogyakarta based adaptation CARTER models. CARTER is model based on SERVQUAL dimensions in addition with new dimension called "Compliance with Islamic law" which is suitable for the Islamic banking industry. Research was conducted by distributing questionnaires to 200 customers consisting of four Islamic banking in Yogyakarta. The analysis method used Structural Equation Model (SEM). The conclusions from this study regarding customer satisfaction about service quality in islamic banks has been above the moderate (high enough). The Factors that give big effect for customer's satisfaction in islamic banking are responsiveness, compliance, and empathy. With analysis of variance was concluded that the quality of every Islamic banks do not have significant differences.
\end{abstract}

Keywords: satisfaction; quality of service; compliance; CARTER Model

\begin{abstract}
Abstrak.
Tujuan dari penelitian ini adalah untuk mengetahui faktor-faktor kualitas layanan yang mempengaruhi kepuasan nasabah, kriteria terpenting yang dapat mempengaruhi kepuasan nasabah dan menganalisis tingkat kepuasan nasabah di masing-masing bank Islam di Yogyakarta dengan adaptasi model CARTER. CARTER adalah model yang didasarkan pada dimensi SERVQUAL, dengan dimensi baru yang disebut "Kepatuhan dengan hukum Islam" yang sesuai untuk industri perbankan syariah. Penelitian dilakukan dengan menyebarkan kuesioner kepada 200 nasabah yang terdiri dari empat perbankan syariah di Yogyakarta. Metode analisis yang digunakan Structural Equation Model (SEM). Kesimpulan dari penelitian ini mengenai kepuasan pelanggan tentang kualitas pelayanan di bank syariah telah di atas moderat (cukup tinggi). Faktor yang memberikan efek besar bagi kepuasan pelanggan di perbankan syariah adalah faktor responsiveness, compliance, dan empathy. Dengan analisis varians disimpulkan bahwa kualitas setiap bank syariah tidak memiliki perbedaan yang signifikan.
\end{abstract}

Kata kunci: kepuasan; kualitas layanan; kepatuhan; Model CARTER

Diterima: 5 Mei 2016; Direvisi: 25 Juli 2016; Disetujui: 8 September 2016 


\section{PENDAHULUAN}

Perkembangan perbankan syariah di Indonesia diawali dengan berdirinya Bank Muamalat Indonesia (BMI) dan Bank-bank Pembiayaan Rakyat Syariah (BPRS) sejak tahun 1992. Eksistensi bank syariah semakin meningkat setelah muncul Undang-Undang No 21 Tahun 2008 tentang perbankan syariah. Undangundang tersebut menjadikan pendirian bank syariah semakin mantap dikarenakan bank konvensional diperbolehkan membuka unit usaha syariah. Dengan diberlakukannya Undang-undang tersebut, diapresiasi oleh perbankan konvensional yang mulai membidik Usaha Syariah dengan membuka Bank Umum Syariah. Pada tahun 2015 di Indonesia sudah terdapat dua Bank Umum Syariah (BUS).

Perbankan syariah dalam hal bidang penyedia jasa memiliki karakteristik yang berbeda dengan perbankan konvensional. Perbedaan yang mendasar antara bank syariah dengan bank konvensional adalah terletak pada praktik menjalankan operasional bisnisnya, dimana operasionalnya berbasis prinsip syariah, dan prinsip inilah yang menjadi daya tarik yang tinggi bagi nasabah untuk memanfaatkan jasa bank syariah

Sebagai entitas bisnis yang berorientasi pada profit, bank syariah dituntut untuk tidak hanya mencari keuntungan semata (profit oriented) tanpa mempertimbangkan fungsi dan tujuannya sebagai sebuah entitas bisnis syariah yang berlandaskan pada konsep Al Quran dan Al sunnah (maqasid syari'ah). Sebagai lembaga intermediasi bank syariah ikut berperan dalam penyaluran dana masyarakat dan menyalurkannya pada sektor riil dengan kombinasi produk yang ditawarkan sesuai dengan syariah.

Dengan pesatnya perkembangan bank syariah saat ini, maka kualitas layanan merupakan faktor kunci yang akan menjadi keunggulan daya saing. Hal ini terjadi karena bank sebagai suatu perusahaan jasa, mempunyai ciri berupa mudah ditirunya suatu produk yang telah dipasarkan. Oleh karena itu bank syariah sudah sewajarnya dapat memberikan kualitas layanan yang prima sehingga mampu mendapatkan keunggulan kompetitif dari bank lain. Pendirian bank-bank syariah yang semakin menjamur menyebabkan persaingan antar bank syariah menjadi 
sangat ketat, sehingga memunculkan pertanyaan yang mendasar mengenai bagaimana kepuasan nasabah bank syariah, kemudian faktor-faktor apa yang mampu memberikan pengaruh kepuasan terbesar untuk nasabah dan bagaimana persepsi nasabah terhadap kepuasan di antara bank-bank syariah yang saat ini sedang berkembang. Nasabah merasakan perbedaan yang signifikan sehingga secara psikis akan lebih memilih pada suatu merek bank syariah ataukah nasabah merasakan tidak ada perbedaan antara layanan antara bank syariah satu dengan yang lain.

Kualitas layanan merupakan faktor kunci yang akan menjadi keunggulan daya saing di dunia perbankan saat ini. Metode pengukuran kualitas layanan yang biasa digunakan untuk mengukur kualitas pada perbankan konvensional serta banyak digunakan secara luas adalah metode SERVQUAL. Metode SERVQUAL didasarkan pada "Gap Model" yang dikembangkan oleh Parasuraman, et al. (1988, 1991, 1993, 1994). Metode SERVQUAL didasarkan pada lima dimensi yaitu tangible, reliability, responsiveness, assurance, dan empathy. Namun kelima dimensi kualitas layanan tersebut bersifat general (pengukuran kualitas untuk bank konvensional), sehingga jika diterapkan pada perusahaan yang memiliki karakteristik khusus seperti perbankan islam perlu mendapatkan modifikasi. Keunikan bank syariah dalam hal compliance yaitu pemenuhan hukum Islam dalam operasionalnya tidak bisa disama ratakan dengan pengukuran yang sama dengan bank konvensional

Othman dan Owen (2001) mengembangkan model pengukuran kualitas jasa untuk mengukur kualitas jasa yang dijalankan dengan prinsip syariah, khususnya bisnis perbankan syariah. Model ini disebut sebagai Model CARTER. Model CARTER merupakan suatu pengukuran kualitas layanan perbankan syariah dengan 6 dimensi yaitu: compliance, assurance, reliability, tangible, empathy, dan responsiveness, yang secara keseluruhan terdiri dari 34. Sehingga dapat diketahui bahwa perbedaan pengukuran kualitas pada model SERVQUAL milik Parasuraman dan model CARTER terletak pada dimensi Compliance. Dimensi Compliance ini memiliki arti kemampuan dari perusahaan untuk memenuhi hukum Islam dan beroperasi di bawah prinsip-prinsip ekonomi dan perbankan Islam. 
Najat Abdurahim (2010) melakukan penelitian dengan mengadopsi model CARTER untuk meneliti service quality. Penelitian ini mengambil lokasi di 10 kota yang memiliki tingkat pertumbuhan umat muslim yang pesat di Inggris, diantaranya London, Birmingham, Manchester, Nottingham, Leicester, Coventry, Derby, Peterborough, Loughborough dan Luton. Penelitian tersebut menggunakan kuesioner yang didistribusikan kepada 350 nasabah bank Islam di Inggris. Dalam penelitian ini didapatkan kesimpulan bahwa dimensi kualitas jasa yang dapat mempengaruhi kepuasan nasabah pada Islamic Bank di Inggris terdiri dari 5 faktor. Faktor pertama, Responsiveness merupakan faktor paling besar yang dapat mempengaruhi kepuasan nasabah diantara faktor lainnya dengan prosentase sebesar 16,47\%. Faktor kedua, Credibility meliputi kepercayaan nasabah terhadap bank, reputasi dan kejujuran bank dalam operasionalnya sehingga secara personal dapat mempengaruhi contact person antara bank dengan nasabah sebesar 15, 95\%. Faktor ketiga, Islamic Tangible meliputi aspek fisik bank sebesar 11,57\%. Faktor keempat Accesibiity meliputi kemudahan akses jasa dan ketepatan waktu dalam melakukan layanan jasa, sebesar 10,96\% dan terakhir Bank Image meliputi reputasi bank secara proaktif dapat mempengaruhi psikis nasabah, sebesar 10,08\%.

\section{METODE}

Penelitian ini dilaksanakan dengan melakukan studi terhadap empat bank syariah di Yogyakarta, yaitu Bank Muamalat Indonesia, BNI Syariah, BTN Syariah dan BPD DIY Syariah. Sampel pada penelitian ini adalah sejumlah nasabah dari ke empat bank yang ada di Yogyakarta, yaitu Bank Muamalat Indonesia, BNI Syariah, BTN Syariah dan BPD DIY Syariah. Penelitian ini menggunakan 6 dimensi dan 34 aitem, dengan total responden nasabah banks syariah 200 (Ghazali, 2008). Pegambilan sampel dilakukan dengan menyebar kuesioner secara langsung ke empat bank tersebut. Metode yang dipergunakan adalah purposive sampling dan convenience sampling.

Teknik analisis yang dipergunakan dalam penelitian ini ialah dengan menggunakan analisis lajur. Dalam penelitian ini yang menjadi variabel eksogenus 
adalah kepuasan nasabah terhadap kualitas layanan bank (service quality), sedangkan untuk variabel endogenus adalah compliance, assurance, reliability, tangible, empathy, dan responsiveness.

Definisi operasional keenam dimensi tersebut dijabarkan lebih lanjut oleh Othman and Owen (2001) sebagi berikut:

1. D1: Compliance (1-5): kemampuan untuk memenuhi hukum Islam dan beroperasi dibawah prinsip-prinsip syariah.

a. Menjalankan prinsip dan hukum Islam

b. Tidak ada pembayaran bunga baik untuk tabungan maupun pinjaman

c. Menerapkan ketentuan layanan produk secara Islami

d. Kesempatan mendapatkan pinjaman bebas bunga

e. Menerapkan ketentuan pembagian keuntungan investasi

2. D2: Assurance (6-10): pengetahuan dan kesopanan karyawan (baik verbal dan tulisan) dan kemampuan mereka memberikan rasa aman dan percaya kepada pelanggan.

a. Karyawan yang sopan dan bersahabat

b. Menyediakan saran-saran/nasehat-nasehat keuangan

c. Interior kantor dan ruang tunggu yang nyaman

d. Bank Syariah menyediakan akses informasi rekening

e. Tim manajemen yang berpengalaman dan memiliki pengetahuan luas

3. D3: Reliability (11-15): kemampuan untuk memiliki performa layanan yang dijanjikan, dapat diandalkan dan akurat.

a. Pemberian layanan yang menyenangkan (waktu layanan yang cepat)

b. Penyediaan produk dan layanan yang luas

c. Keamanan dalam bertransaksi yang terjamin

d. Waktu (jam) layanan yang optimal

e. Pengintegrasian penggunaan nilai tambah layanan (Ketersediaan ATM)

4. D4: Tangible (16-20): aspek yang terlihat secara fisik misal peralatan, personel, dan bahan-bahan komunikasi.

a. Tampilan kantor dan fasilitas fisik yang menarik

b. Transaksi yang cepat dan efisien

c. Jam operasi yang jelas 
d. Menyediakan sekat-sekat atau pembatas loket yang jelas

e. Menyediakan layanan penarikan kas dengan hak istimewa

5. D5: Emphaty (21-28): kemampuan karyawan untuk peduli dan memberikan perhatian secara personal kepada pelanggan.

a. Lokasi yang mudah dijangkau

b. Nama, reputasi dan citra yang mudah dikenali

c. Bank memiliki aset dan modal yang besar

d. Penyediaan area parkir yang memadai

e. Kerahasiaan data nasabah yang terjamin

f. Manajemen yang meyakinkan

g. Penyediaan produk dan layanan yang menguntungkan

h. Penetapan tarif layanan yang rendah

6. D6: Responsiveness (29-34): keinginan untuk membantu pelanggan dan memberikan layanan yang cepat.

a. Penyediaan ketentuan konsultasi keuangan

b. Karyawan bersedia membantu konsumen

c. Cara karyawan dalam melayani konsumen secara Islami

d. Menyediakan pinjaman dengan jangka waktu pelunasan yang menguntungkan

e. Layanan yang cepat dan efisien

f. Mempunyai cabang yang tersedia dengan cukup.

\section{HASIL DAN PEMBAHASAN}

Terdapat enam dimensi yang digunakan untuk mengetahui kualitas jasa terhadap nasabah, yaitu complience, assurance, reliability, tanggible, empathy dan responsiveness. Perhitungan statistik deskriptif mendapatkan sekor rata-rata jawaban pada tiap dimensi berada pada kisaran 3.049 - 3.204, dan sebagai kesatuan kualitas pelayanan menghasilkan sekor rata-rata sebesar 3.126.

Nilai yang digunakan dalam penelitian ini adalah 1 - 5 dimana 1 mewakili sangat rendah dan 5 mewakili sangat tinggi. Nilai rata-rata tentang kualitas layanan berada lebih dari skala 3. Hal ini menunjukkan tanggapan nasabah 
terhadap kualitas pelayanan sudah di atas moderat, namun karena masih di bawah skala 4 maka belum bisa dinyatakan tinggi. Dimensi complience sebagai keunikan yang dimiliki bank syariah akan pemenuhan hukum Islam dianggap kurang memiliki dampak yang signifikan. Terlihat dari keenam dimensi kualitas layanan, nasabah bank syariah merasakan unsur kualitas layanan dimensi complience memiliki nilai paling rendah dan assurance yang memiliki sekor paling tinggi.

Tabel 1. Deskriptif Kualitas Pelayanan

\begin{tabular}{lcccc}
\hline & Jumlah & \multicolumn{2}{c}{ Rerata } & \\
Kualitas Pelayanan & Pertanyaan & Hitung & Tertimbang & Keterangan* \\
\hline Complience & 5 & 15.245 & 3.049 & Cukup Tinggi \\
Assurance & 5 & 16.020 & 3.204 & Cukup Tinggi \\
Reliability & 5 & 15.855 & 3.171 & Cukup Tinggi \\
Tanggible & 5 & 15.340 & 3.068 & Cukup Tinggi \\
Emphaty & 8 & 24.795 & 3.099 & Cukup Tinggi \\
Responsiveness & 6 & 18.975 & 3.163 & Cukup Tinggi \\
Kualitas Pelayanan & 34 & 106.230 & 3.126 & Cukup Tinggi \\
\hline
\end{tabular}

Sumber : Hasil pengujian statistik deskriptif

Besarnya koefesien gamma untuk dimensi kualitas pelayanan responsiveness adalah sebesar 0.8802 , paling besar dibandingkan dimensi lainnya. Nilai paling besar menunjukan variabel yang paling dominan merefleksikan kepuasan nasabah. Kaitannya dengan fungsi kepuasan maka menginterpretasikan bahwa, dalam pengaruh kualitas pelayanan responsiveness memberikan kontribusi paling besar (77.47\%). Kemudian secara berturut-turut disusul oleh complience, empathy, tanggible, reliability dan assurance.

Tabel 2. Nilai Gamma

\begin{tabular}{lcc}
\hline Dimensi & $\gamma$ & Kontribusi (\%) \\
\hline Complience & 0.8799 & 0.7743 \\
Assurance & 0.4864 & 0.2366 \\
Reliability & 0.5583 & 0.3117 \\
Tanggible & 0.7475 & 0.5587 \\
Emphaty & 0.8442 & 0.7127 \\
Responsiveness & 0.8802 & 0.7747 \\
\hline \multicolumn{2}{l}{ Sumber : Hasil pengujian statistik deskriptif }
\end{tabular}

Adapun detail nilai gama dari tiap item CARTER yang dapat mempengaruhi kepuasan nasabah dapat dilihat dalam Tabel 3. Dalam Tabel 3 
dapat diketahui nilai gamma tertinggi dari tiap variabel CARTER, dimana nilai gamma tinggi berarti item tersebut memberikan sumbangan terbesar terhadap dimensi yang dirasakan nasabah, diantaranya: Responsiveness, yaitu berupa penyediaan ketentuan konsultasi keuangan dan cara karyawan dalam melayani konsumen secara islami. Compliance, berupa kesempatan mendapatkan pinjaman bebas bunga. Emphaty, yaitu manajemen yang meyakinkan. Tangible, yaitu tampilan kantor dan fasilitas fisik yang menarik. Reliability, yaitu keamanan dalam bertransaksi yang terjamin. Assurance, yaitu bank Syariah menyediakan akses informasi rekening.

Tabel 3. Nilai Gama Tiap Item

\begin{tabular}{|c|c|c|}
\hline Item CARTER & $\gamma$ & Kontribusi (\%) \\
\hline $\begin{array}{l}\text { 1. Responsiveness } \\
\text { a. Penyediaan ketentuan konsultasi keuangan } \\
\text { b. Karyawan bersedia membantu konsumen } \\
\text { c. Cara karyawan dalam melayani konsumen secara } \\
\text { islami } \\
\text { d. Menyediakan pinjaman dengan jangka waktu } \\
\text { pelunasan yang menguntungkan } \\
\text { e. Layanan yang cepat dan efisien } \\
\text { f. Mempunyai cabang yang tersedia dengan cukup }\end{array}$ & $\begin{array}{l}0.86 \\
0.83 \\
0.86\end{array}$ & $\begin{array}{l}0.74 \\
0.69 \\
0.74\end{array}$ \\
\hline $\begin{array}{l}\text { 2. Compliance } \\
\text { a. Menjalankan prinsip dan hukum islam } \\
\text { b. Tidak ada pembayaran bunga baik untuk tabungan } \\
\text { maupun pinjaman } \\
\text { c. Menerapkan ketentuan layanan produk secara islami } \\
\text { d. Kesempatan mendapatkan pinjaman bebas bunga }\end{array}$ & $\begin{array}{l}0.78 \\
0.81 \\
\end{array}$ & $\begin{array}{l}0.64 \\
0.61 \\
0.61 \\
0.67 \\
\end{array}$ \\
\hline $\begin{array}{l}\text { 3. Emphaty } \\
\text { a. Lokasi yang mudah dijangkau } \\
\text { b. Nama, reputasi dan citra yang mudah dikenali } \\
\text { c. Bank memiliki aset dan modal yang besar } \\
\text { d. Penyediaan area parkir yang memadai } \\
\text { e. Kerahasiaan data nasabah yang terjamin } \\
\text { f. Manajemen yang meyakinkan } \\
\text { g. Penyediaan produk dan layanan yang } \\
\text { menguntungkan } \\
\text { h. Penetapan tarif layanan yang rendah }\end{array}$ & $\begin{array}{l}0.57 \\
0.55 \\
0.53 \\
0.50 \\
0.72 \\
0.73 \\
0.54\end{array}$ & $\begin{array}{l}0.32 \\
0.30 \\
0.28 \\
0.25 \\
0.52 \\
0.53 \\
0.29 \\
0.49\end{array}$ \\
\hline $\begin{array}{l}\text { 4. Tangible } \\
\text { a. Tampilan kantor dan fasilitas fisik yang menarik } \\
\text { b. Transaksi yang cepat dan efisien } \\
\text { c. Jam operasi yang jelas } \\
\text { d. Menyediakan sekat-sekat atau pembatas loket yang } \\
\text { jelas }\end{array}$ & $\begin{array}{l}0.87 \\
0.79 \\
0.82 \\
0.68\end{array}$ & $\begin{array}{l}0.76 \\
0.63 \\
0.67 \\
0.46\end{array}$ \\
\hline
\end{tabular}




\begin{tabular}{|l|l|l|}
\hline e. Menyediakan layanan penarikan kas dengan hak & 0.71 & 0.51 \\
\hline 5stimewa & & \\
\hline 5eliability & 0.74 & 0.55 \\
a. Pemberian layanan yang menyenangkan (waktu & 0.76 & 0.58 \\
layanan yang cepat) & 0.80 & 0.64 \\
b. Penyediaan produk dan layanan yang luas & 0.69 & 0.48 \\
c. Keamanan dalam bertransaksi yang terjamin & 0.73 & 0.53 \\
d. Waktu (jam) layanan yang optimal & & \\
e. Pengintegrasian penggunaan nilai tambah layanan & 0.79 & 0.62 \\
\hline (Seperti ketersediaan ATM) & 0.81 & 0.65 \\
assurance & 0.80 & 0.64 \\
b. Maryawan yang sopan dan bersahabat & 0.83 & 0.68 \\
keuangan saran-saran/nasehat-nasehat & 0.76 & \\
d. Interior kantor dan ruang tunggu yang nyaman & & \\
e. Tim manajemen yang berpengalaman dan memiliki & 0.57 \\
\hline pengetahuan luas & & \\
\hline
\end{tabular}

Sumber: Hasil pegujian SEM

Uji varian (ANOVA) dapat digunakan untuk menguji apakah dua buah sampel atau lebih mempunyai varians populasi yang sama ataukah tidak (Tjiptono, 2004). Untuk melakukan perbandingan kepuasan nasabah pada tiap bank kita menggunakan uji anova dengan ketentuan $\alpha=0,05$ atau $5 \%$ sehingga dikatakan signifikan jika nilai $\alpha \leq 0,05$. Terlihat dalam tabel 5 bahwa nilai signifikan $\alpha \geq 0,05$ yaitu sebesar 0.416 maka dapat disimpulkan bahwa persepsi nasabah terhadap kualitas jasa pada empat bank dianggap tidak signifikan. Kualitas dari tiap bank dianggap tidak ada perbedaan, jika dilihat nilai mean tiap bank berbeda-beda namun tetap tidak ada perbedaan yang berarti. Hal ini dapat menggambarkan bahwa tiap bank syariah mencoba untuk menawarkan kualitas layanan semaksimal mungkin, sehingga nasabah merasakan kenyamanan transaksi yang sama pada tiap bank. Selain itu produk yang sama di setiap bank syariah menjadikan nasabah menilai semua bank syariah sama saja. Menurut Al Arif (2010), setiap bank seharusnya memiliki keunikan produk yang mampu membedakan produk antar bank. 
Tabel 4. Kualitas dan kepuasan dalam Uji F

\begin{tabular}{lcccccccc}
\hline \multicolumn{3}{c}{ Kualitas dalam Uji F } & \multicolumn{4}{c}{ Kepuasan dalam Uji F } \\
\multicolumn{1}{c}{ Bank } & N & Mean & F & Sig. & N & Mean & F & Sig. \\
\hline BTN Syariah & 45 & 102,84 & & & 45 & 9,20 & & \\
BNI Syariah & 55 & 109,16 & 0.953 & 0.416 & 55 & 9,60 & 0.396 & 0.756 \\
BPD DIY & 45 & 108,60 & & & 45 & 9,09 & & \\
Muamalat & 55 & 106,23 & & & 55 & 9,65 & & \\
\hline
\end{tabular}

Sumber: Hasil pengujian data primer

Sama halnya dengan kualitas, dalam kepuasan terlihat dalam Tabel 4 bahwa nilai signifikan $\alpha \geq 0,05$ yaitu sebesar 0.756 maka dapat disimpulkan bahwa kepuasan secara keseluruhan yang dirasakan oleh nasabah pada tiap bank syariah tidak ada perbedaan. Hal ini dapat terindikasi bahwa unsur kepercayaan yang tinggi dari nasabah terhadap pemilihan bank mampu menyebabkan kepuasan nasabah (pemilihan bank sesuai dengan keinginan dan kebutuhan nasabah). Pengaruh psikologis nasabah dalam pemilihan bank, dapat juga dipengaruhi oleh kemampuan bank-bank syariah saat ini yang sedang melakukan pendekatan secara personal (knowing your customer).

Hasil ini sedikit berbeda dengan Othman dan Owen (2001), dimana melakukan penelitian dengan mencoba membuat suatu model kualitas jasa yang dapat digunakan untuk mengukur kepuasan nasabah pada Bank Syariah yang ada di Kuwait. Penelitian tersebut dilakukan dengan menyebarkan kuesioner kepada 360 nasabah Bank Syariah di Kuwait. Dalam penelitiannya diketemukan 6 dimensi yang membentuk kepuasan nasabah pada bank syariah yaitu: complience, assurance, reliability, tangible, empathy, dan responsiveness. Dalam penelitian ini terbentuk 6 dimensi yang dikenal dengan CARTER yang terdiri dari 34 item. Hasil penelitiannya menunjukkan bahwa perbankan syariah harus memperbaiki service financial karena kuatnya kompetisi diantara perbankan yang ada di Kuwait dan cepatnya perubahan teknologi yang semakin maju. Bank Syariah harus memberikan perhatian yang lebih untuk perubahan tersebut dan memulai untuk menetapkan strategi agar dapat memberikan suatu produk yang berkualitas dan pelayanan yang maksimal untuk kepuasan nasabah. 


\section{SIMPULAN}

Kesimpulan dalam penelitian ini, dimensi kualitas CARTER memberikan kontribusi signifikan terhadap kualitas layanan dan kepasan nasabah terhadap Bank Syariah. Dari hasil penelitian didapatkan penilaian kualitas layanan bank serta kepuasan yang dirasakan nasabah kepada bank syariah sudah diatas moderat. Faktor-faktor kualitas jasa yang memberikan kepuasan nasabah terbesar sampai yang terkecil adalah responsiveness, Compliance, emphaty, tanggible, reliabioity dan assurance. Pemberian kemudahan dalam konsultasi keuangan dan produk bebas bunga sesuai dengan syariah menjadi aspek prioritas pembentuk kepuasan nasabah dalam melakukan transaksi di bank syariah. Dalam analisis varian dapat disimpulkan bahwa persepsi nasabah terhadap kualitas pada empat bank dianggap tidak signifikan. Kualitas dari tiap bank dianggap tidak ada perbedaan. Sama halnya dengan uji perbedaan terhadap kepuasan nasabah pada masing-masing bank syariah, dapat disimpulkan bahwa kepuasan yang dirasakan oleh nasabah pada tiap bank syariah tidak ada perbedaan.

\section{PUSTAKA ACUAN}

Abdurahim, N. (2010). Service Quality of English Islamic Bank. (Tesis Tidak Dipublikasikan. Bournemouth: Bournemouth University.

Al Arif, M.N.R. (2010). Dasar-dasar Pemasaran Bank Syariah. Bandung: Alfabeta.

Ferdinant, A. (2005). Structural Equation Model. Semarang : CD Indoprint.

Ferdinant, A. (2006). Metode Penelitian Manajemen. Semarang: CV. Indoprint.

Ghazali, I. (2008). Structural Equation Model, Teori dan Aplikasi dengan Lisrel 8.80. Semarang: BP Undip.

Lovelock, C.H. (1992). Managing Service: Marketing, Operating and Human Resources. New Jersey: Prentice Hall International.

Muhammad. (2002). Manajemen Bank Syari'ah. Yogyakarta: UPP AMP YKPN.

Muhammad. (2004). Manajemen Dana Bank Syariah. Yogyakarta: Ekonisia.

Nasution, M.N. (2004). Manajemen Jasa Terpadu. Bogor: Ghalia Indonesia.

Othman, A. \& L. Owen. (2001). Adopting and Measuring Customer Service Quality (SQ) in Islamic Banks: A Case Study in Kuwait Finance House. International Journal of Islamic Financial Services Vol. 3. No. 1, hlm. 51-60. 
Parasuraman, A. et.al. (1985). A Conceptual Model of Service Quality and Its Implication for Future Research. Journal of Marketing. Vol. 49, hlm. 91-100. Parasuraman, Z \& Berry. (1995). Delivering Quality Service, Balancing Customer Perception and Expectation. New York: The Free Press.

Purnama, N. (2006). Manajemen Kualitas Perspektif Global. Yogyakarta: Ekonisia.

Soviyanti, E. \& Wakhid. (2007). Adapting Islamic Banks CARTER Model: An Empirical Study in Riau's Syariah Banks, Indonesia. Journal of CARTER Model, Vol. 2, hlm. 81-90.

Syukur, A. (2006). Kepuasan Nasabah Terhadap Customer Service dalam Bidang Pelayanan Jasa Pada Bank Tabungan Negara (BTN) Syariah di Yogyakarta. Skripsi Tidak Diterbitkan. Yogyakarta: UIN Sunan Kalijaga.

Tahir, M. \& N. Mazlina. (2007). Service Quality Gap And Customers Satisfactions Of Commercial Bank In Malaysia. International Review of Business Research Paper. Vol. 3 (4 ), hlm. 301-310.

Tjiptono, F \& D. Anastasia. (2003). Total Quality Management. Yogyakarta: Andi.

Zeithaml, et.al. (1996). Services Marketing. New York: McGrawHill. 